\title{
Namaszczenie Jezusa w Betanii (Mt 26,6-13)
}

Ewangelia według św. Mateusza zawiera trzykrotną zapowiedź męki, śmierci i zmartwychwstania Jezusa. Za pierwszym razem Chrystus oznajmił swoim uczniom, że musi udać się do Jerozolimy, że wiele wycierpi od starszych, arcykapłanów i uczonych w Piśmie oraz że zostanie zabity, ale trzeciego dnia zmartwychwstanie (Mt 16,21). Niemalże identyczne informacje zawiera również i druga zapowiedź, którą Jezus wypowiedział w Galilei. Zaznaczył wówczas, że Syn Człowieczy będzie wydany w ludzkie ręce i zabity, jednak trzeciego dnia powstanie z martwych (Mt 17,22-23). Za trzecim razem Chrystus znów wspomniał o Jerozolimie, o arcykapłanach i uczonych w Piśmie, którzy skażą Syna Człowieczego na śmierć, oraz o swoim zmartwychwstaniu. W tym fragmencie pojawił się nadto motyw pogan, którzy wyszydzą, ubiczują i ukrzyżują Jezusa (Mt 20,17-19).

Gdy powyższe zapowiedzi zaczęły się realizować, Judasz zdradził Chrystusa za trzydzieści srebrników (Mt 26,14-16), uczniowie się rozproszyli (Mt 26,56), a Piotr trzykrotnie zaparł się swojego Mistrza (Mt 26,69-75). Zupełnie inaczej było z niewiastami. To one były obecne pod krzyżem (Mt 27,55-56), czuwały przy grobie (Mt 27,61), planowały namaścić martwe ciało Jezusa w niedzielny poranek (Mt 28,1-8) oraz rozpoczęły głoszenie wielkanocnego orędzia (Mt 28,7-10). Do tej drugiej grupy należała również pewna anonimowa kobieta, która w Betanii namaściła Chrystusa na dzień Jego pogrzebu (Mt 26,6-13).

W niniejszym artykule zostanie omówiona perykopa Mt 26,6-13. W pierwszym punkcie passus ten będzie przebadany pod kątem literackim. Następnie

${ }^{1}$ Ksiądz Łukasz Florczyk - ur. 1984, kapłan diecezji opolskiej, doktor teologii biblijnej, absolwent Instytutu Nauk Biblijnych Katolickiego Uniwersytetu Lubelskiego Jana Pawła II w Lublinie, adiunkt w Katedrze Egzegezy Ksiąg Nowego Testamentu na Wydziale Teologicznym Uniwersytetu Opolskiego; e-mail: lukasz.florczyk@uni.opole.pl; ORCID: 0000-0002-4490-3522. 
zostanie zaprezentowany zwięzły komentarz do poszczególnych wierszy. Natomiast trzeci punkt artykułu będzie zawierał teologiczne przesłanie rozpatrywanego tekstu biblijnego. Analiza perykopy o namaszczeniu Jezusa w Betanii będzie zatem przebiegać według standardów metody historyczno-krytycznej.

Celem podjętych badań jest m.in. porównanie passusu Mt 26,6-13 z tekstami paralelnymi występującymi w Piśmie Świętym. Umożliwi to lepsze zrozumienie procesu redakcji Mateuszowego opowiadania o namaszczeniu Chrystusa. Autor artykułu pragnie również pochylić się nad strukturą analizowanego fragmentu i zastanowić się nad tym, czy wyodrębnione części perykopy można ze sobą zestawić na zasadzie analogii. Warto także zastanowić się nad tym, kim była owa anonimowa kobieta, która namaściła głowę Jezusa w Betanii, i jak należy interpretować jej gest.

\section{Analiza literacka}

Omówienie biblijnej perykopy o namaszczeniu Jezusa w Betanii (Mt 26,6-13) należy rozpocząć od gruntownego przebadania kwestii literackich. Na tę analizę będą się składały następujące elementy: delimitacja tekstu, grecki tekst perykopy, przekład na język polski, krytyka tekstu, kontekst bliższy perykopy, porównanie omawianego passusu z biblijnymi tekstami paralelnymi, proces redakcji, forma literacka oraz struktura badanej perykopy.

\section{Delimitacja tekstu}

Pierwsza część narracji pasyjnej (Mt 26,1-56) rozpoczyna się od ostatniej zapowiedzi męki Jezusa oraz od zaprezentowania spisku arcykapłanów i starszych ludu wymierzonego przeciwko Chrystusowi (Mt 26,1-5), a kończy się wzmianką o pojmaniu Jezusa, którego dokonali ludzie wysłani przez arcykapłanów i starszych (Mt 26,47-56). Pomiędzy tymi dwoma fragmentami znajduje się jeszcze sześć innych scen: namaszczenie Chrystusa w Betanii (Mt 26,6-13), pierwszy etap zdrady Judasza (Mt 26,14-16), Jezusowe polecenie wystosowane do uczniów, aby przygotowali Paschę (Mt 26,17-19), ostatnia wieczerza, podczas której Chrystus wyjawił swego zdrajcę i ustanowił Eucharystię (Mt 26,20-30), przepowiednia trzykrotnego zaparcia się Piotra i rozproszenia uczniów (Mt 26,31-35) oraz modlitwa Jezusa w Getsemani (Mt 26,36-46). W ujęciu Mateusza Chrystus posiadał wiedzę na temat tego, co miało się wydarzyć w bliskiej i dalszej przyszłości. Jezus zapowiedział bowiem zdradę Judasza (Mt 26,21-25), zwątpienie i rozproszenie uczniów (Mt 26,31), zaparcie się Piotra (Mt 26,34), swoją śmierć przez ukrzyżowanie (Mt 26,2) i pospieszny pochówek (Mt 26,12), ale też zmartwychwstanie (Mt 26,32), głoszenie Ewan- 
gelii po całym świecie (Mt 26,13) oraz ucztę ze swoimi uczniami w królestwie Ojca (Mt 26,29) ${ }^{2}$.

Perykopa o namaszczeniu Chrystusa w Betanii (Mt 26,6-13) otoczona jest dwoma fragmentami zawierającymi motyw spiskowania przeciwko Jezusowi. Bohaterami pierwszego z nich są arcykapłani i starsi ludu zebrani w pałacu Kajfasza, najwyższego kapłana (Mt 26,3-5), a drugiego - Judasz Iskariota, który przybył do arcykapłanów z propozycją wydania Chrystusa (Mt 26,14-16). Namaszczenie głowy Jezusa, którego dokonała pewna anonimowa kobieta, miało miejsce w domu Szymona Trędowatego w Betanii. Świadkami tego wydarzenia byli uczniowie Chrystusa i najprawdopodobniej sam gospodarz. Owo namaszczenie było ewidentnym czynem miłości pośród aktów wrogości kierowanych w stronę Jezusa przez arcykapłanów, starszych ludu i Judasza. Zatem strukturę tekstu Mt 26,3-16 można przedstawić w następujący sposób:

A — spiskowanie przeciwko Jezusowi przez arcykapłanów i starszych

B - namaszczenie Chrystusa w Betanii

A' - spiskowanie przeciwko Jezusowi przez Judasza ${ }^{3}$

Z jednej strony perykopa Mt 26,6-13 łączy się z wierszami Mt 26,1-2, gdyż w obu tekstach pojawia się Jezus wraz z uczniami oraz motyw zbliżającej się śmierci, a z drugiej strony passus o namaszczeniu Chrystusa w Betanii jawi się jako jednostka literacka niezależna od jej bliskiego kontekstu i nosząca znamiona kompletnej oraz logicznie spójnej narracji. Usunięcie tego fragmentu nie spowodowałoby braku ciągłości narracyjnej pomiędzy Mt 26,3-5 (spiskowanie przeciwko Jezusowi przez arcykapłanów i starszych) i Mt 26,14-16 (spiskowanie przeciwko Jezusowi przez Judasza). Tekst Mt 26,6-13 funkcjonuje w strukturze tego rozdziału jako rodzaj narracyjnego nawiasu, który na moment zawiesza bieg głównego wątku narracji, ale jednocześnie wprowadza nowe pierwiastki tematyczne stanowiące teologiczne tło dla relacji o ściągnięciu ciała Chrystusa z krzyża i pospiesznym pochówku (Mt 27,57-61).

\section{Tekst grecki perykopy ${ }^{4}$}

26,6 Tou de Iēsou genomenou en Bēthania(i) en oikia(i) Simōnos tou leprou,

26,7 prosēlthen autō(i) gynē echousa alabastron myrou barytimou kai katecheen epi tēs kefalēs autou anakeimenou.

26,8 idontes de hoi mathētai ēganaktēsan legontes: eis ti hē apōleia hautē?

26,9 edynato gar touto prathēnai pollou kai dothēnai ptōchois.

2 D. Garland, Reading Matthew. A Literary and Theological Commentary on the First Gospel, Macon 2001, s. 251-252.

${ }^{3}$ R. Gardner, Matthew, Scottdale 1991, s. 367.

${ }^{4}$ E. Nestle i in., Novum Testamentum Graece, Stuttgart $2013^{28}$, s. 87. 
26,10 Gnous de ho Iēsous eipen autois: ti kopous parechete tē(i) gynaiki? ergon gar kalon èrgasato eis eme;

26,11 pantote gar tous ptōchous echete meth' heautōn, eme de ou pantote echete;

26,12 balousa gar haute to Myron touto epi tou sōmatos mou pros to entafiasai me epoiēsen.

26,13 amēn legō hymin, hopou ean kērychthē(i) to euangelion touto en holō(i) tō(i) kosmō(i), lalēthēsetai kai ho epoiēsen hautē eis mnēmosynon autēs.

\section{Przekład na język polski}

26,6 Gdy zaś Jezus był w Betanii, w domu Szymona Trędowatego,

26,7 podeszła do Niego pewna kobieta mająca alabastrowy flakonik bardzo drogiego ${ }^{\mathrm{a}}$ olejku ${ }^{\mathrm{b}} \mathrm{i}$ wylała na Jego głowęc, gdy leżał przy stole.

26,8 Widząc to, uczniowie oburzyli się mówiąc: Po co to marnotrawstwo?

26,9 Można to było drogo sprzedać i rozdaćb ubogim.

26,10 Wiedząc o tym, Jezus powiedział im: Dlaczego sprawiacie przykrość tej kobiecie? Dobry uczynek spetnita względem Mnie.

26,11 Biednych bowiem zawsze będziecie mieli pośród siebie, Mnie zaś nie zawsze będziecie mieli.

26,12 Ona wylawszy ten olejek na moje ciało, uczyniła to na mój pogrzeb.

26,13 Zaprawdę mówię wam: Gdziekolwiek na catym świecie będzie głoszona ta Ewangelia, na jej pamiatkę będzie mówione i to, co ona uczyniła.

\section{Krytyka tekstu}

\section{6,7}

a) w tym miejscu Kodeks Watykański, Kodeks Cypryjski, Kodeks Waszyngtoński, Kodeks Tischendorfa IV, Kodeks Sangalleński, kodeks majuskułowy 0293, rodziny kodeksów minuskułowych $\mathrm{f}^{1}$ i $\mathrm{f}^{13}$, kodeksy minuskułowe: 579, 700,1241 , lekcjonarz 844 i większość przekładów syryjskich zawierają słowo barytimou („drogocenny”). Natomiast Kodeks Synajski, Kodeks Aleksandryjski, Kodeks Bezy, Kodeks Królewski, Kodeks z Koridethi, kodeksy minuskułowe: $33,565,892,1424$ oraz przekłady syryjskie w miejsce barytimou mają synonim polytimou. Być może miała na to wpływ paralela w J 12,3;

b) lekcję echousa alabastron myrou zawiera większość podstawowych świadków: Kodeks Synajski, Kodeks Watykański, Kodeks Bezy, Kodeks Królewski, Kodeks z Koridethi, kodeks majuskułowy 0293, rodzina kodeksów minuskułowych $\mathrm{f}^{13}$, kodeksy minuskułowe: $33,700,892$, lekcjonarz 844 oraz cała tradycja łacińska. Wersję alabastron myrou echousa zawierają: Kodeks Aleksandryjski, Kodeks Cypryjski, Kodeks Waszyngtoński, Kodeks Tischendorfa IV, Kodeks Sangalleński, rodzina kodeksów minuskułowych $\mathrm{f}^{1}$ oraz większość manuskryp- 
tów minuskułowych, np. 565, 579, 1241, 1424. Nieco zmienioną wersję: alabastron echousa myrou zawiera m.in. papirus $\mathrm{P}^{45}$;

c) genetivus tès kefalēs występuje w Kodeksie Synajskim, Kodeksie Watykańskim, Kodeksie Bezy, Kodeksie z Koridethi, kodeksie majuskułowym 0293, rodzinach kodeksów minuskułowych $\mathrm{f}^{1} \mathrm{i} \mathrm{f}^{13}$ oraz w kodeksie minuskułowym 700 . Natomiast accusativus tēn kefalēn proponują: papirus $\mathrm{P}^{45}$, Kodeks Aleksandryjski, Kodeks Cypryjski, Kodeks Królewski, Kodeks Waszyngtoński, Kodeks Tischendorfa IV, Kodeks Sangalleński, lekcjonarz 844 oraz większa część kodeksów minuskułowych, np. 33, 565, 579, 892, 1241 i 1424.

26,8

a) w tym miejscu niektórzy świadkowie dodają zaimek autou. Taką dłuższą lekcję możemy znaleźć w Kodeksie Aleksandryjskim, Kodeksie Cypryjskim, Kodeksie Waszyngtońskim, Kodeksie Tischendorfa IV, Kodeksie Sangalleńskim, rodzinie kodeksów minuskułowych $\mathrm{f}^{1}$, manuskryptach minuskułowych: 565, 579, 1241 i 1424, kodeksach zawierających starołacińskie przekłady: c, f, q oraz w przekładach syryjskich i sahidyckich. Krótsza wersja (bez zaimka autou) występuje w papirusie P45, Kodeksie Synajskim, Kodeksie Watykańskim, Kodeksie Bezy, Kodeksie Królewskim, Kodeksie z Koridethi, kodeksie majuskułowym 0293, rodzinie kodeksów minuskułowych $\mathrm{f}^{13}$, lekcjonarzu 844, kodeksach minuskułowych: 33, 700 i 892 oraz w przekładach starołacińskich i koptyjskich. Najprawdopodobniej uzupełnienie tekstu o zaimek autou miało na celu wygładzenie stylu ${ }^{5}$.

26,9

a) Kodeks Cypryjski, Kodeks Tischendorfa IV, rodzina kodeksów minuskułowych $\mathrm{f}^{13}$, lekcjonarz 844 , kodeksy minuskułowe: $33,579,700,1241$ i 1424 oraz wiele kodeksów starołacińskich dodają w tym miejscu słowo to myron („olejek”). Być może miała na to wpływ paralela w Mk 14,5;

b) niektórzy świadkowie po dothēnai dodają jeszcze słowo tois, które odnosi się do pieniędzy zyskanych ze sprzedaży olejku. Taką wersję można spotkać w Kodeksie Aleksandryjskim, Kodeksie Bezy, Kodeksie Cypryjskim, Kodeksie Waszyngtońskim, Kodeksie Tischendorfa IV, Kodeksie Sangalleńskim oraz w wielu kodeksach minuskułowych, np. 700, 1241 i 1424. Krótszą, ale za to nieco trudniejszą wersję zawierają świadkowie, którzy cieszą się wielkim autorytetem: Kodeks Synajski, Kodeks Watykański, Kodeks Królewski, Kodeks z Koridethi, kodeks majuskułowy 0293, rodzina kodeksów minuskułowych $\mathrm{f}^{1}$ i $\mathrm{f}^{13}$, lekcjonarz

5 A. Banaszek, Relacja o wydarzeniu w Betanii w świetle analizy literacko-historycznej (Mt 26,6-13; Mk 14,3-9; Łk 7,36-50; J 12,1-11), w: Studia z biblistyki, t. VII, red. R. Bartnicki, Warszawa 1994, s. 163-240, tu: s. 170. 
844 oraz kodeksy minuskułowe: 33, 565, 579 i 892. Najprawdopodobniej dodanie przez kopistów słowa tois służyło wyjaśnieniu trudnego miejsca ${ }^{6}$.

\section{Kontekst bliższy perykopy}

Perykopa o namaszczeniu Jezusa w Betanii stanowi element opisów pasyjnych. Rozdział Mt 26 rozpoczyna się od ostatniej zapowiedzi męki (Mt 26,1-2). Chrystus oznajmił swoim uczniom, że już niebawem zostanie wydany na ukrzyżowanie. Następnie ewangelista Mateusz opisał moment zebrania się arcykapłanów i starszych ludu w pałacu Kajfasza, najwyższego kapłana (Mt 26,3-5). Podczas narady zadecydowano o podstępnym pochwyceniu Jezusa i o Jego zabiciu. Nie chciano tego jednak czynić w czasie Paschy, by nie wywołać wzburzenia wśród ludu. Józef Flawiusz zanotował, że w 65 roku po Chr. na to święto przybyło do Jerozolimy 2700000 pielgrzymów. Najprawdopodobniej była to liczba wyolbrzymiona. Joachim Jeremias stwierdził, że świętujących Paschę w Jerozolimie mogło być ok. 180 tys. (z czego 25-30 tys. to sami mieszkańcy Świętego Miasta)7.

Po opowiadaniu o namaszczeniu w Betanii ewangelista Mateusz umieścił wzmiankę o zdradzie Judasza (Mt 26,14-16). Apostoł ten udał się do arcykapłanów z propozycją wydania Jezusa. Ci zgodzili się na to i przekazali mu w zamian trzydzieści srebrników. Odtąd Judasz Iskariota szukał stosownej możliwości, aby wydać Chrystusa. Po tym passusie występują jeszcze następujące sekcje, które bezpośrednio poprzedzają wydarzenie zmartwychwstania Jezusa: ostatnia wieczerza (Mt 26,17-35), Chrystus w Ogrójcu (Mt 26,36-56), Jezus przed swoimi sędziami (Mt 26,57-27,31), Chrystus na Golgocie (Mt 27,32-66). Zatem perykopa o namaszczeniu Jezusa (Mt 26,6-13) wiąże się ściśle z Jego śmiercią.

\section{Porównanie omawianego passusu z biblijnymi tekstami paralelnymi}

Motyw namaszczenia Chrystusa jest obecny we wszystkich czterech Ewangeliach (Mt 26,6-13; Mk 14,3-9; Łk 7,36-50; J 12,1-11). Jednak tylko w Ewangelii według św. Łukasza wydarzenie to rozegrało się podczas publicznej działalności Jezusa i w żaden sposób nie wiązało się z Jego męką oraz śmiercią. Warto zatem prześledzić wszystkie powyższe teksty i wypunktować elementy wspólne oraz te treści, które podają tylko i wyłącznie poszczególni ewangeliści.

We wszystkich czterech Ewangeliach można znaleźć wzmiankę o tym, że Chrystus został namaszczony olejkiem, gdy przebywał w domu i siedział za stołem. Wszyscy ewangeliści zanotowali, że namaszczenia dokonała kobieta. U Ma-

\footnotetext{
${ }^{6}$ Tamże.

7 T. Brzegowy, Doroczne święta pielgrzymkowe Izraela, „Ruch Biblijny i Liturgiczny” 36 (1983), s. 98-115, tu: s. 112.
} 
teusza i Marka była to osoba anonimowa, u Łukasza bezimienna kobieta, która prowadziła w mieście grzeszne życie, a u Jana Maria — siostra Marty i Łazarza. Wszystkie Ewangelie podejmują również motyw buntu oraz zaznaczają, że Jezus pozytywnie odniósł się do czynu kobiety i stanął po jej stronie.

Gdy chodzi o elementy wspólne u trzech ewangelistów, to należy wymienić następujące motywy: Betania (Mt, Mk, J); Szymon (u Mateusza i Marka był to Szymon Trędowaty, natomiast u Łukasza - faryzeusz Szymon); bezimienna kobieta (Mt, Mk, Łk); alabastrowe naczynie (Mt, Mk, Łk); bardzo drogi olejek (Mt, Mk, J); namaszczenie głowy (u Mateusza i Marka kobieta namaściła głowę Jezusa, a u Łukasza Chrystus tylko wzmiankował o takim namaszczeniu, którego powinien był dokonać Szymon w związku z przyjęciem gościa). Mateusz, Marek i Jan wspomnieli również o oburzeniu z powodu użycia drogiego olejku. Buntujące się osoby twierdziły, że olejek można było sprzedać, a uzyskane w ten sposób pieniądze przekazać na rzecz ludzi ubogich. Ci sami ewangeliści przytoczyli również słowa Chrystusa, w których bronił On namaszczającej Go kobiety. Zaznaczył, że było to namaszczenie na dzień Jego pogrzebu oraz że uczniowie zawsze będą mieli ubogich wokół siebie, a Jego — nie zawsze.

Motywy wspólne, które występują w dwóch Ewangeliach, to: Szymon Trędowaty (Mt, Mk); wyraźna wzmianka o posiłku/uczcie (Łk, J); szlachetny/prawdziwy olejek nardowy (Mk, J); namaszczenie głowy Jezusa (Mt, Mk); namaszczenie nóg Chrystusa (Łk, J); ocieranie nóg Jezusa włosami (Łukasz umieścił ten moment przed namaszczeniem Chrystusa, a Jan — już po namaszczeniu); marnotrawstwo olejku (Mt, Mk); trzysta denarów (Mk, J) i droga sprzedaż olejku (Mt, Mk); mowa Jezusa o dobrym uczynku kobiety (Mt, Mk) oraz prorocki logion Chrystusa na temat głoszenia Ewangelii po całym świecie (Mt, Mk).

Na koniec warto jeszcze przyjrzeć się tym treściom, które podają tylko i wyłącznie poszczególni ewangeliści. Mateusz stwierdził, że na czyn kobiety oburzyli się uczniowie. Ewangelista Marek zanotował, że kobieta - przed namaszczeniem głowy Jezusa - rozbiła flakonik, w którym umieszczony był olejek. Hojny gest względem Chrystusa oburzył tylko niektóre osoby, które zaczęly szemrać, gdyż wolały sprzedać olejek drożej niż za trzysta denarów i zupełnie inaczej spożytkować zarobione w ten sposób pieniądze.

W Ewangelii według św. Łukasza Jezus przyjął gościnę w domu faryzeusza Szymona. To właśnie tam znalazła Go kobieta, która prowadziła w mieście grzeszne życie. Ewangelista Łukasz — jedyny - wspomniał o tym, że grzesznica łzami oblała nogi Chrystusa, a potem je całowała. To wydarzenie wzbudziło u Szymona wiele wątpliwości co do osoby Jezusa. Faryzeusz uznał bowiem, że gdyby jego gość był prorokiem, to zapewne by wiedział, kim jest kobieta, która do Niego podeszła. Następnie Chrystus opowiedział gospodarzowi przypowieść o dwóch dłużnikach. Jeden z nich był winny wierzycielowi pięćset denarów, a drugi — pięćdziesiąt. Jednak po pewnym czasie wierzyciel umorzył 
oba długi. Ta historia miała uzmysłowić Szymonowi, że bardziej kocha ten, komu więcej darowano. Ewangelista Łukasz przytoczył dalej wypowiedź Jezusa, w której ukazał On kontrast pomiędzy faryzeuszem a grzesznicą. Ta różnica dotyczyła prostych czynności, które wiązały się z przyjmowaniem gości. Były to: podanie wody do obmycia nóg, przekazanie pocałunku i namaszczenie głowy oliwą. Gospodarz - w przeciwieństwie do kobiety — nie spełnił tych czynności względem Chrystusa. Ewangelista Łukasz podjął również wątek odpuszczenia grzechów owej kobiecie. Ta czynność wywołała niemałe poruszenie wśród współbiesiadników, którzy zaczęli pytać, kim jest Jezus, skoro nawet grzechy odpuszcza. Perykopę kończy wzmianka o tym, że kobieta została ocalona dzięki swej wierze i odeszła w pokoju.

W Ewangelii według św. Jana namaszczenie Chrystusa dokonało się na sześć dni przed Paschą. Jezus przebywał w domu Łazarza i razem z nim zasiadał przy stole. W tym czasie Marta posługiwała, a Maria wzięła funt olejku i namaściła nim stopy Jezusa. Ewangelista Jan zanotował, że cały dom napełnił się wonią olejku. Hojny gest Marii spotkał się z buntem Judasza, który wolał sprzedać olejek za trzysta denarów, a pieniądze przekazać ubogim. Narrator zaznaczył jednak, że Judasz wcale nie dbał o biednych. Był natomiast złodziejem i wykradał pieniądze z trzosa. Passus o namaszczeniu Chrystusa kończy wzmianka o tym, że do Betanii przybyło mnóstwo Żydów, którzy chcieli zobaczyć Jezusa i wskrzeszonego przez Niego Łazarza. Tymczasem arcykapłani nosili się z zamiarem zabicia nie tylko Chrystusa, lecz również Łazarza, gdyż wielu ludzi z jego powodu uwierzyło Jezusowi.

\section{Proces redakcji tekstu perykopy}

Wielu egzegetów jest zdania, że pierwotne opowiadanie o namaszczeniu Chrystusa wchodziło w skład bardzo starej tradycji betańskiej i początkowo nie było powiązane z opisami męki. Dopiero później zostało ono dołączone do poprzedzającego dzieło Marka opowiadania pasyjnego. Marek dotarł do tego tekstu i włączył go do swojej Ewangelii, gdyż doskonale odpowiadał on jego założeniom teologicznym. Ewangelista rozbudował jednak wątek pasyjny (Mk 14,8) oraz kwestię dotyczącą ludzi biednych (Mk 14,6b)

Z kolei Mateusz przejął od Marka opowiadanie o namaszczeniu Jezusa w Betanii, ale wprowadził do niego pewne zmiany. Były one niewielkie i służyły wygładzeniu tekstu. Nie da się ukryć, że Mateuszowa wersja opowiadania jest znacznie krótsza (124 słowa u Marka i 109 słów u Mateusza). Mateusz uprościł niektóre wypowiedzi Markowe (np. Mk 14,3a i Mt 26,6) oraz opis olejku, poza tym pominął motyw rozbicia naczynia i skrócił odpowiedź Chrystusa na bunt

\footnotetext{
${ }^{8}$ A. Banaszek, Relacja o wydarzeniu w Betanii..., s. 212-214, 236.
} 
uczniów. Z drugiej strony ewangelista ten rozbudował obraz Jezusa jako Nauczyciela i Pedagoga oraz stonował kwestię biednych i motyw szemrania uczniów. Charakterystyczne dla Mateusza było również częste stosowanie participium, wyjaśnianie trudniejszych form literackich spotykanych u Marka (np. Mk 14,3b i Mt 26,7b) oraz tworzenie sekwencji dialogowych (Mt 26,8.10).

\section{Forma literacka}

Perykopa Mt 26,6-13 rozpoczyna się od opisu namaszczenia głowy Jezusa, którego w Betanii dokonała pewna anonimowa kobieta (Mt 26,6-7). Następnie umieszczona została wstawka narracyjna sygnalizująca motyw oburzenia uczniów (Mt 26,8a) oraz ich wypowiedź w formie mowy niezależnej na temat marnotrawstwa olejku, możliwości jego sprzedaży i pomocy ubogim (Mt 26,8b-9). Kolejna wstawka narracyjna informuje o tym, że Chrystus zauważył bunt swoich uczniów (Mt 26,10a). Po tym tekście umieszczona została wypowiedź Jezusa w formie mowy niezależnej na temat czynu kobiety, ludzi biednych, zbliżającego się pogrzebu oraz głoszenia Ewangelii po całym świecie (Mt 26,10b-13). Rudolf Bultmann stwierdził, że perykopa Mt 26,6-13 jest biograficznym apoftegmatem zakończonym prorockim logionem Chrystusa. Uczony ten zauważył również, że ośrodkiem całego opowiadania jest dialog, jaki wywiązał się pomiędzy Jezusem a Jego uczniami ${ }^{10}$.

\section{Struktura badanej perykopy}

Opowiadanie o namaszczeniu Jezusa w Betanii można podzielić na trzy części. Są to: ekspozycja (Mt 26,6-7), konflikt (Mt 26,8-9) oraz rozwiązanie (Mt 26,10-13). Struktura tego passusu przedstawia się następująco:

1. Ekspozycja

$$
\begin{array}{ll}
\text { miejsce zdarzenia } & \text { (Mt 26,6) } \\
\text { namaszczenie Jezusa } & \text { (Mt 26,7) }
\end{array}
$$

2. Konflikt

$$
\text { oburzenie uczniów (Mt 26,8-9) }
$$

3. Rozwiązanie

9 Tamże, s. 180, 215, 222, 236-237; A. Paciorek, Ewangelia wedtug świętego Mateusza (rozdziaty 14-28). Wstęp — przektad z oryginatu — komentarz, (Nowy Komentarz Biblijny: Nowy Testament I/2), Częstochowa 2008, s. 538; W. Grundmann, Das Evangelium nach Matthäus, (Theologischer Handkommentar zum Neuen Testament 1), Berlin 1981, s. 532; W. Davies, D. Allison, A Critical and Exegetical Commentary on the Gospel According to Saint Matthew, London-New York 2004, s. 441-442; U. Luz, H. Koester, Matthew 21-28. A Commentary, transl. J.E. Crouch, Minneapolis-Augsburg 2005, s. 334-335.

${ }^{10}$ A. Paciorek, Ewangelia wedtug świętego Mateusza ..., s. 538. 


$$
\begin{array}{ll}
\text { odpowiedź Chrystusa } & (\text { Mt 26,10-12) } \\
\text { prorocki logion Jezusa } & (\text { Mt 26,13) }
\end{array}
$$

Warto również przyjrzeć się dialogowi pomiędzy Chrystusem i Jego uczniami, gdyż obie jego części mają tę samą strukturę. Ów dialog koncentruje się na osobie Jezusa. Do Niego należy ostatnie słowo. Ewangelista Mateusz chciał, by czytelnicy identyfikowali się z Chrystusowym punktem widzenia. Dlatego też wypowiedź Jezusa stanowi połowę perykopy Mt 26,6-13. Wiersze Mt 26,6-10a zawierają 50 słów, a wersety Mt 26,10b-13 - 59 słów. Zarówno wypowiedź uczniów, jak i mowa Chrystusa poprzedzone są imiesłowem, po którym występuje de (,zaś”). Na uwagę zasługuje paralela pytań. Pytanie uczniów oraz pytanie Jezusa zaczyna się od słowa $t i$. Na dalszą część perykopy składa się jedno zdanie wypowiedziane przez uczniów i trzy, które wyszły z ust Chrystusa. Wszystkie te teksty rozpoczynają się od słowa gar („bowiem”). Z kolei końcowy komunikat Jezusa na temat głoszenia Ewangelii po całym świecie zaczyna się od słynnego amēn legō hymin („Amen/Zaprawdę mówię wam”). Struktura perykopy Mt 26,6-13 — opartej na paraleli pytań oraz wypowiedzi uczniów i Jezusa prezentuje się w następujący sposób:

(1) Otwarcie akcji - scena namaszczenia Chrystusa $\quad$ Mt 26,6-7

(2) Dialog pomiędzy Jezusem i Jego uczniami: Mt 26,8-12

$$
\begin{array}{cl}
\text { A - pytanie uczniów } & \text { Mt 26,8 } \\
\text { B - uzasadnienie reakcji uczniów (jedno zdanie) } & \text { Mt 26,9 } \\
\text { A'- pytanie Chrystusa } & \text { Mt 26,10a } \\
\text { B' - uzasadnienie reakcji Chrystusa (trzy zdania) } & \text { Mt 26,10b-12 } \\
\text { (3) Zakończenie z obietnicą } & \text { Mt 26,13 }
\end{array}
$$

\footnotetext{
11 Tamże, s. 537; A. Sand, Das Evangelium nach Matthäus, Regensburg 1986, s. 519-521; A. Banaszek, Relacja o wydarzeniu w Betanii..., s. 223. Analizując perykopę Mt 26,6-13, łatwo zauważyć, że ma ona strukturę koncentryczną, a jej poszczególne części można ze sobą zestawić na zasadzie analogii. W centrum opowiadania znajduje się wzmianka o reakcji uczniów, którzy oburzyli się, widząc, jak pewna kobieta wylała na głowę Jezusa drogocenny olejek. Struktura badanego passusu prezentuje się w następujący sposób: A - miejsce pobytu Chrystusa: Betania (Mt 26,6); B - namaszczenie Jezusa (Mt 26,7); C — oburzenie uczniów (Mt 26,8-9); B' - wypowiedź Jezusa po namaszczeniu (Mt 26,10-12); A' - miejsce głoszenia Ewangelii: cały świat (Mt 26,13).

12 J. Gnilka, Das Matthäusevangelium, (Herders Theologischer Kommentar zum Neuen Testament: I/2), Freiburg-Basel-Wien 1988, s. 385; A. Banaszek, Relacja o wydarzeniu w Betanii..., s. 190; W. Davies, D. Allison, A Critical and Exegetical Commentary..., s. 441; U. Luz, H. Koester, Matthew 21-28..., s. 334.
} 


\section{Komentarz}

Przeprowadziwszy analizę literacką, zaprezentuję zwięzły komentarz do poszczególnych wierszy wchodzących w skład perykopy o namaszczeniu Jezusa w Betanii (Mt 26,6-13). Umożliwi to zdefiniowanie teologicznego przesłania badanego tekstu.

\section{Miejsce zdarzenia (Mt 26,6)}

Akcja perykopy Mt 26,6-13 rozgrywa się w Betanii („dom biednych”). Była to wioska umiejscowiona ok. $3 \mathrm{~km}$ na wschód od Jerozolimy ${ }^{13}$. To właśnie w tej miejscowości mieszkali przyjaciele Jezusa - Maria, Marta i Łazarz (Łk 10,38-42), który tam został wskrzeszony (J 11,1-44). Stamtąd też rozpoczął się triumfalny pochód Chrystusa do Jerozolimy (Mk 11,1-11).

Tym razem Jezus zatrzymał się w domu niejakiego Szymona Trędowatego. Najprawdopodobniej był to człowiek, który został już uzdrowiony ze swej dolegliwości. W przeciwnym razie Szymon nie mógłby mieszkać w swoim domu, przyjmować gości, a nawet przebywać w mieście (Kpł 13,45-46). Przy jego imieniu pozostawiono jednak wcześniejszy przydomek. Być może wynikało to z ówczesnej popularności imienia Szymon w Palestynie. Również przy imieniu Mateusza pozostawiono nazwę jego wcześniejszego zajęcia. W wykazie powołanych przez Jezusa apostołów został on nazwany celnikiem, choć zapewne od momentu włączenia go do grona Dwunastu przestał nim już być (Mt 10,3) ${ }^{14}$.

\section{Namaszczenie Jezusa (Mt 26,7)}

Gdy Jezus przebywał w domu Szymona Trędowatego, podeszła do Niego pewna kobieta. Zapewne już jej pojawienie się uznano za skandal, skoro kobietom nie wolno było uczestniczyć w takich spotkaniach. Wyjątek stanowiły jedynie usługujące niewiasty ${ }^{15}$. Ewangelista Mateusz nie podał imienia owej kobiety. Mogła nią być jedna z niewiast idących za Jezusem (Łk 8,1-3), Maria, siostra Łazarza (J 12,3-8) lub jakaś nierządnica (Łk 7,36-50).

${ }^{13}$ M. Milne, Betania, w: Encyklopedia biblijna, red. P. Achtemeier, red. wyd. pol. W. Chrostowski, tłum. M. Pachciarek, Warszawa 1999, s. 91-92, tu: s. 91.

${ }^{14}$ Hieronim ze Strydonu, Komentarz do Ewangelii według św. Mateusza, (Źródła Myśli Teologicznej), Kraków 2008, s. 186; S. Fausti, Wspólnota czyta Ewangelię wedtug św. Mateusza, tłum. zbiorowe, Częstochowa 2007, s. 554; S. Szymik, Jezus jako gość w świetle ewangelii kanonicznych, „Biblica et Patristica Thoruniensia” 9 (2016) 2, s. 125-141, tu: s. 134-135.

${ }^{15}$ R. Popowski, L. Coleman, Nowy Testament dla moderatorów, (Prymasowska Seria Biblijna), Warszawa 2010, s. 70-71. 
Anonimowa kobieta przyniosła ze sobą alabastrowy flakonik, w którym znajdował się olejek. Alabaster, czyli miękki kamień o kremowym kolorze, był sprowadzany z Egiptu. To właśnie w takich naczyniach zazwyczaj przechowywano wonności, by na długo pozostały one świeże i cieszyły ludzi swoim zapachem. O powszechności występowania takich przedmiotów świadczą wykopaliska. $\mathrm{Na}$ przykład w Palestynie archeologom udało się odnaleźć tysiące małych, alabastrowych flakoników na wonności ${ }^{16}$.

Ewangelista Mateusz zanotował, że w tym alabastrowym flakoniku znajdował się drogi olejek. Greckie słowo myron oznacza olejek o pięknym zapachu (często na bazie oliwy oraz wzbogacony różnymi technikami i aromatami) lub maść. Produkty te uzyskiwano z żywicy pochodzącej z drzew balsamicznych, które rosły w Arabii i Somalii. Mirrę wykorzystywano jako kadzidło, składnik kosmetyków, perfum i leków oraz w obrzędach pogrzebowych ${ }^{17}$.

Kobieta podeszła do Jezusa z alabastrowym flakonikiem olejku, gdy Chrystus znajdował się już przy stole. Najprawdopodobniej wokół stołu umieszczone były niskie sofy. Biesiadnicy spoczywali na nich w pozycji półleżącej. To właśnie wówczas kobieta wylała ów drogi olejek na głowę Jezusa. Ewangelista Mateusz nie użył w tym miejscu czasownika aleifō („namaszczać”), lecz katacheō („wylewać"). Wynika z tego, że kobieta nie tyle namaściła Chrystusa, co wylała na Jego głowę całą zawartość alabastrowego flakonika. Namaszczenie głowy ważnych gości było powszechnie znanym i praktykowanym obyczajem. Jednak to namaszczenie w Betanii nie było zwykłym i kurtuazyjnym gestem, lecz świadczyło o wielkim szacunku i uwielbieniu, jakie owa anonimowa kobieta żywiła względem Jezusa. W ten sposób można mówić o kontraście pomiędzy domem Szymona Trędowatego a pałacem arcykapłana, gdzie spiskowano przeciwko Chrystusowi i gdzie zapadła decyzja o Jego zabiciu' ${ }^{18}$.

\section{Oburzenie uczniów (Mt 26,8-9)}

Hojny gest kobiety względem Chrystusa spotkał się z oburzeniem i niezadowoleniem uczniów, którzy widzieli w nim marnotrawstwo i niepotrzebną rozrzutność. Myśleli oni zupełnie inaczej niż Jezus. Nic więc dziwnego, że ich kry-

16 B. Newman, P. Stine, A Handbook on the Gospel of Matthew, New York 1992, s. 793.

${ }_{17}$ C.S. Keener, Komentarz historyczno-kulturowy do Nowego Testamentu, thum. Z. Kościuk, (Prymasowska Seria Biblijna), Warszawa 2000, s. 70; A. Nalewaj, Opis namaszczenia w Betanii w czwartej Ewangelii (J 12,1-8) w świetle lektury Pieśni nad pieśniami, w: Jak śmierć potężna jest miłość. Księga pamiątkowa ku czci Księdza Profesora Juliana Warzechy SAC (1944-2009), red. W. Chrostowski, Ząbki 2009, s. 270-286, tu: s. 281; R. Bartnicki, Przygotowania do śmierci Jezusa (Mk 14,1-11), „Warszawskie Studia Teologiczne” 27 (2014) 2, s. 203-221, tu: s. 212.

${ }_{18}$ R. Popowski, L. Coleman, Nowy Testament ..., s. 71; U. Luz, H. Koester, Matthew 21-28..., s. 336-337; A. Paciorek, Ewangelia wedlug świętego Mateusza ..., s. 539. 
tyka spadła nie tylko na ową kobietę, ale też na Chrystusa, który nie protestował, lecz pozwolił wylać na swoją głowę drogi olejek. Być może ewangelista Mateusz nawiązał w tym tekście do funkcjonowania pierwszych gmin chrześcijańskich, w których istniały pewne rozbieżności w kwestii zarządzania wspólnymi dobrami materialnymi ${ }^{19}$.

Uczniowie Jezusa byli zdania, że zmarnowany olejek można było znacznie lepiej spożytkować. Należało go drogo sprzedać, a uzyskane w ten sposób pieniądze przeznaczyć na rzecz ubogich. Poza tym zbliżająca się Pascha sprzyjała materialnemu wspieraniu ludzi biednych. Można również przypuszczać, że wzmożone zainteresowanie uczniów losem ubogich wynikało z przebywania w bliskości Chrystusa, z obserwacji dokonywanych przez Niego cudów oraz ze słuchania Jego nauk.

\section{Odpowiedź Chrystusa (Mt 26,10-12)}

W wierszu 26,10 ewangelista Mateusz zanotował, że Jezus zauważył oburzenie swoich uczniów. Następnie zapytał, dlaczego sprawiają przykrość kobiecie, która namaściła $\mathrm{Mu}$ głowę olejkiem. Czytelnika tej perykopy zadziwia to, że kobieta cały czas milczała. Nikomu nie wyjaśniła swego gestu, ani też nie broniła się przed opinią uczniów. Podobną postawę przyjmie już niebawem przesłuchiwany Chrystus (Mt 26,63; 27,14).

Jezus pochwalił kobietę, stwierdzając, że wykonała względem Niego dobry uczynek. Greckie słowo kalos można przetłumaczyć jako „dobry” lub „piękny”. Należy pamiętać, że w judaizmie istniało rozróżnienie dobrych uczynków na jałmużnę i inne akty miłosierdzia (np. grzebanie umarłych). Ta pierwsza pobożna praktyka polegała na przekazaniu pieniędzy ludziom cierpiącym niedostatek. Natomiast uczynki miłości nierzadko wymagały poświęcenia, ofiary i osobistego zaangażowania oraz mogły być kierowane zarówno w stronę ubogich, jak i bogatych, żywych, ale i zmarłych. To właśnie akty miłosierdzia uważano za doskonalsze od jałmużny ${ }^{20}$.

Chrystus pouczył swoich uczniów, że ubogich, którym chcieli pomóc przez spieniężenie olejku, zawsze będą mieli wokół siebie i jeszcze nie raz nadarzy się okazja, żeby ich szczodrze wspomóc (Pwt 15,11). Jednak Jezusa uczniowie nie zawsze będą mieli przy sobie. W owej chwili On był ubogim i cierpiacym. Zbliżała się godzina Jego śmierci i przejścia z tego świata do Ojca (J 13,1). Do

19 J. Homerski, Ewangelia według św. Mateusza. Wstęp — przekład z oryginału — komentarz, (Pismo Święte Nowego Testamentu: III/1), Poznań 2004, s. 327.

20 A. Paciorek, Ewangelia wedtug świętego Mateusza..., s. 540; J. Homerski, Ewangelia wedtug św. Mateusza ..., s. 327; D. Garland, Reading Matthew..., s. 254; M. Rosik, Duszpasterski komentarz do Nowego Testamentu. Ewangelia wg św. Mateusza (Mt 14,1-28,20), Tarnów 2010, s. 116; G. Albrecht, M. Albrecht, Matthew, Milwaukee 1996, s. 376. 
tego momentu Chrystus nawiązał w dalszej części swojej wypowiedzi. Stwierdził bowiem, że kobieta namaściła Mu ciało na dzień pogrzebu. Tym samym byłby to gest prorocki, choć nie wiadomo, czy kobieta była tego świadoma. Zwłoki - jeszcze przed złożeniem do grobu - namaszczano olejkami. Bardzo często skrapiano nimi także całun. W ten sposób chciano oddać cześć zmarłemu oraz ochronić jego ciało przed rozkładem. Jezus wiedział, że w dniu śmierci nie będzie czasu, by przed zachodem słońca namaścić Jego ciało. Rzymscy żołnierze z pewnością nie zatroszczyliby się o właściwy, żydowski pochówek człowieka, który został skazany na haniebną śmierć przez ukrzyżowanie, czy wręcz nań nie pozwoliliby. Choć Nikodem i Józef z Arymatei zrobili, co mogli (J 19,38-42), to jednak pobożne niewiasty czuły potrzebę, by w niedzielny poranek udać się do grobu i namaścić ciało Jezusa (Łk 23,55-24,1). Nie było to jednak potrzebne, gdyż Chrystus zmartwychwstał ${ }^{21}$.

Zatem bezimienna kobieta, która w Betanii namaściła Jezusa, rzeczywiście dokonała tego na dzień Jego pogrzebu. Uprzedzająco namaściła ciało Chrystusa, gdyż nie uczyniono tego przed złożeniem do grobu lub zrobiono to pospiesznie.

\section{Prorocki logion Jezusa (Mt 26,13)}

Wiersz Mt 26,13 zawiera prorocki logion Chrystusa. Rozpoczyna się on od słynnego amēn legō hymin („Amen/Zaprawdę mówię wam”). Wyraz amēn oznacza „niech tak będzie”, „oto jest”, „otóż to”, ,zaprawdę”. W całym Nowym Testamencie tylko Jezus używał tego słowa na początku zdania. Chciał w ten sposób wyraźnie coś podkreślić, ukazać ważność jakiegoś stwierdzenia lub podnieść wagę swojej wypowiedzi ${ }^{22}$.

W domu Szymona Trędowatego Chrystus zapowiedział, że euangelion touto („,ta Ewangelia”) będzie głoszona po całym świecie. Ta powszechna proklamacja miała również dotyczyć gestu kobiety, która namaściła Jezusa w Betanii. Słowo euangelion mogło oznaczać opowiadanie o męce lub wskazywać na Mateuszowe dzieło ${ }^{23}$. Do dziś chrześcijanie na całym świecie wspominają czyn tej bezimiennej niewiasty. To opowiadanie jest bowiem ważnym elementem zarówno narracji pasyjnej, jak i Ewangelii według św. Mateusza.

${ }^{21}$ A. Paciorek, Ewangelia wedlug świętego Mateusza ..., s. 540-541; G. Albrecht, M. Albrecht, Matthew, s. 376; M. Rosik, Duszpasterski komentarz..., s. 117-118.

22 J. Watson, Stowo greckie na każdy dzień roku. Inspiracje z Nowego Testamentu, thum. W. Tasak, Warszawa 2017, s. 380; J. Nolland, The Gospel of Matthew. A Commentary on the Greek Text, Grand Rapids-Carlisle 2005, s. 1055.

${ }^{23}$ A. Paciorek, Ewangelia wedlug świętego Mateusza..., s. 541; A. Świderkówna, Rozmowy o Biblii. Nowy Testament, Warszawa 2000, s. 178-180. 


\section{Przesłanie teologiczne}

Po przeprowadzeniu analizy literackiej i zaprezentowaniu zwięzłego komentarza do poszczególnych wierszy przyszedł czas, by przedstawić kluczowe tematy teologiczne tekstu Mt 26,6-13.

\section{Znaczenie Chrystusowego namaszczenia}

Perykopa o namaszczeniu Jezusa w Betanii bywa różnie objaśniana. Niektórzy egzegeci są zdania, że $\mathrm{w}$ tym passusie została podkreślona mesjańska godność Chrystusa. Z tą interpretacją wiązał się triumfalny wjazd Jezusa do Jerozolimy. Chrystus — jako namaszczony król (1 Sm 10,1; $1 \mathrm{Krl}$ 1,39; $2 \mathrm{Krl}$ 9,12) - zmierzał do Świętego Miasta, by tam ponieść mękę i umrzeć na krzyżu. Był On mesjańskim królem, a Jego tronem był krzyż. Jednak kontekst uczty/posiłku w domu Szymona Trędowatego, nazwa olejku (myron, a nie elaion) oraz oburzenie uczniów przemawiają raczej przeciwko takiemu wyjaśnieniu $^{24}$. Elaine Mary Wainwright zwróciła uwagę na postać odważnej kobiety, która - w obliczu zbliżającej się męki — okazała Jezusowi współczucie, miłość i miłosierdzie ${ }^{25}$. Wydarzenie w Betanii — zgodnie z wierszem Mt 26,12 - było również interpretowane jako namaszczenie Chrystusa na dzień Jego pogrzebu. Należy pamiętać, że ewangelista Mateusz nie wspomniał w swoim dziele o namaszczeniu ciała Jezusa po śmierci. To właśnie tym drogim olejkiem, który w Betanii spłynął na głowę Chrystusa, będzie pachniało Jego ciało na krzyżu i w grobie. Natomiast po zmartwychwstaniu jego woń będzie się roznosiła wszędzie tam, gdzie głoszona będzie Dobra Nowina ${ }^{26}$.

Szczodry gest bezimiennej kobiety względem Jezusa był uczynkiem miłosierdzia i miłości, który przewyższał zwykłą jałmużnę. Namaszczenie w Betanii symbolizowało szczególne uszanowanie i adorację Chrystusa. Niektórzy egzegeci mówili wprost o wyższości kultu Chrystusa nad posługiwaniem Jezusowi w ludziach biednych. Warto również pamiętać, że w Piśmie Świętym białe szaty oraz namaszczenie głowy wonnym olejkiem były oznakami radości i wesela (Koh 9,8). Na szczególną uwagę zasługuje jeszcze interpretacja podana przez św. Jana Chryzostoma († 407). Twierdził on, że to skruszone serce popchnęło kobietę do tego, by złamała ustalone standardy i weszła do domu Szymona Trędowatego. Oczekiwała bowiem, że Jezus uzdrowi jej duszę z trądu grzechu

${ }^{24}$ A. Paciorek, Ewangelia wedtug świętego Mateusza..., s. 538-540; W. Davies, D. Allison, A Critical and Exegetical Commentary..., s. 448.

${ }^{25}$ U. Luz, H. Koester, Matthew 21-28..., s. 335.

${ }^{26}$ S. Fausti, Wspólnota czyta Ewangelię..., s. 552. 
i z wszelkiej nieczystości, tak jak kiedyś uzdrowił Szymona z trądu, którym pokryte było jego ciało (Comm. Matt. 80,1-2) ${ }^{27}$.

\section{Symbolika drogiego olejku}

Drogi olejek, którym bezimienna kobieta namaściła w Betanii głowę Jezusa, symbolizował okazaną Mu przez nią miłość. Orygenes († 254) przyporządkował zwykły olejek dobrym czynom, olejek, którym zostały namaszczone stopy Jezusa, dziełom miłosierdzia pełnionym przez pokutujących, a olejek, który niewiasta wylała na głowę Chrystusa - czynom wiary, czystości, postowi, modlitwie i cierpliwości (Comm. Matt. 77). Teofilakt († 1107) stwierdził, że namaszczenie stóp Jezusa wiązało się $\mathrm{z}$ uwielbieniem Jego człowieczeństwa, a namaszczenie głowy Chrystusa - z uwielbieniem Jego boskiej natury (En. Matt. 438). Hilary z Poitiers $(† 367)$ widział w kobiecie symbol Kościoła z pogan, który darzy czcia cierpiącego Jezusa (Comm. Matt. 29,2). Bernard z Clairvaux († 1153) dokonał rozróżnienia na olejek skruchy, który posłużył do namaszczenia stóp Jezusa oraz olejek pobożności, który niewiasta wylała Mu na głowę ${ }^{28}$.

Drogi olejek, który posłużył do namaszczenia Chrystusa w Betanii (Mt 26,613), stał się symbolem szczodrości, hojności i bezinteresowności. Tak jak cenny olejek wylany na głowę Jezusa nie był żadną stratą, lecz znakiem miłości i posłużył do namaszczenia Chrystusa na dzień Jego pogrzebu, tak też i przelanej na krzyżu krwi Jezusa nie należy rozpatrywać w kategoriach marnotrawstwa, gdyż przysłużyła się ona do odpuszczenia grzechów i do naszego zbawienia.

\section{Perykopa pelna kontrastów}

Motyw namaszczenia Jezusa w Betanii (Mt 26,6-13) ewidentnie kontrastuje z treściami, które go poprzedzają i które po nim następują. Jakże nie dostrzec różnicy pomiędzy domem Szymona Trędowatego, gdzie Chrystus został ugoszczony przez gospodarza i gdzie pewna kobieta wylała na Jego głowę drogi olejek, a pałacem Kajfasza, najwyższego kapłana, gdzie odbyła się narada arcykapłanów i starszych ludu, którzy zamierzali Jezusa podstępnie pochwycić i zabić (Mt 26,3-5). Widoczna jest również różnica między czynem niewiasty, która namaściła Chrystusa, a postępowaniem Judasza, który zdradził Jezusa i przeszedł na stronę Jego wrogów. To właśnie on udał się do arcykapłanów z propozycją wydania Chrystusa, a gdy otrzymał od nich trzydzieści srebrników, szukał sposobności, by zrealizować swój plan (Mt 26,14-16).

27 A. Paciorek, Ewangelia wedlug świętego Mateusza ..., s. 538-539, 543.

${ }^{28}$ Tamże, s. 543. 
Analizując poszczególne teksty biblijne, w których zawarte są opisy męki, śmierci i zmartwychwstania Jezusa, łatwo zauważyć kontrast pomiędzy apostołami a niewiastami. Judasz zdradził Chrystusa (Mt 26,14-16), uczniowie uciekli (Mt 26,56), a Piotr trzykrotnie wyparł się swojego Mistrza (Mt 26,69-75). Natomiast kobiety były obecne przy ukrzyżowanym Jezusie (Mt 27,55-56), czuwały przy grobie (Mt 27,61), chciały namaścić ciało Chrystusa w niedzielny poranek (Mt 28,1-8) i to właśnie im w pierwszej kolejności została zlecona misja ogłoszenia wielkanocnego orędzia (Mt 28,7-10). Również w domu Szymona Trędowatego niewiasta zachowała się znacznie właściwiej od uczniów. Szczodry gest względem Jezusa był wyrazem jej szacunku. Spotkał się jednak z krytyką uczniów, którzy uznali go za marnotrawstwo. Zatem z jednej strony mamy miłość, dobry uczynek, hojność i zapowiedź Ewangelii życia, a z drugiej strony - egoizm, chęć sprzedaży, oburzenie i sprawianie przykrości ${ }^{29}$. Ostatecznie Chrystus zganił swoich uczniów, pochwalił czyn owej kobiety i stanął po jej stronie.

\section{Podsumowanie}

Perykopa o namaszczeniu Jezusa w Betanii (Mt 26,6-13) jest częścią narracji pasyjnej. Najprawdopodobniej ewangelista Mateusz przejął ten tekst od Marka. Jednak Mateuszowa wersja opowiadania jest znacznie krótsza. Ewangelista ten wprowadził kilka drobnych zmian, np. uprościł opis olejku, który anonimowa kobieta wylała na głowę Jezusa, pominął wzmiankę o rozbiciu naczynia, skrócił mowę Chrystusa po buncie uczniów, stonował kwestię biednych oraz motyw szemrania uczniów. Cechą charakterystyczną wariantu Mateusza jest również częste stosowanie participium oraz tworzenie sekwencji dialogowych (Mt 26,8.10).

Egzegeci doszukali się w perykopie Mt 26,6-13 trzech części: ekspozycji (Mt 26,6-7), konfliktu (Mt 26,8-9) oraz rozwiązania (Mt 26,10-13). Zwrócili również uwagę na paralelę pytań oraz wypowiedzi uczniów i Jezusa (A - pytanie uczniów: Mt 26,8; B — uzasadnienie reakcji uczniów [jedno zdanie]: Mt 26,9; A' - pytanie Chrystusa: Mt 26,10a; B' - uzasadnienie reakcji Chrystusa [trzy zdania]: Mt 26,10b-12). Natomiast autor artykułu dostrzegł w Mt 26,6-13 strukturę koncentryczną, której poszczególne części można ze sobą zestawić na zasadzie analogii (A - miejsce pobytu Chrystusa [Betania]: Mt 26,6; B — namaszczenie Jezusa: Mt 26,7; C — oburzenie uczniów: Mt 26,8-9; B' - wypowiedź Jezusa po namaszczeniu: Mt 26,10-12; A' - miejsce głoszenia Ewangelii [cały świat]: Mt 26,13). W takim wypadku centralnym motywem opowiadania byłaby wzmianka o reakcji uczniów, którzy oburzyli się, widząc, jak pewna kobieta wy-

${ }^{29}$ S. Fausti, Wspólnota czyta Ewangelię..., s. 553. 
lała na głowę Jezusa drogocenny olejek. Chrystus — karcąc swoich uczniów dał im jasno do zrozumienia, że ich postawa nie była właściwa.

Akcja opowiadania rozegrała się w Betanii, w domu Szymona Trędowatego. Pewna kobieta (mogła nią być jedna z niewiast idących za Jezusem: Łk 8,1-3, Maria, siostra Łazarza: J 12,3-8 lub nieznana z imienia nierządnica: Łk 7,36-50) podeszła do Chrystusa z alabastrowym flakonikiem, w którym znajdował się drogi olejek. Niewiasta nie tyle namaściła nim głowę Jezusa, ile wylała na nią całą zawartość naczynia. Nic więc dziwnego, że hojny gest kobiety spotkał się z niezrozumieniem i krytyką uczniów, którzy woleli raczej sprzedać olejek, a uzyskane w ten sposób pieniądze przeznaczyć na rzecz ludzi biednych. Chrystus zganił swoich uczniów, a niewiastę wziął w obronę. Kobieta patrzyła sercem, dlatego też potrafiła poznać, że w tamtej konkretnej chwili to właśnie Jezus był ubogim i cierpiącym człowiekiem. Niewiasta — w przeciwieństwie do uczniów — nic nie wiedziała o potrójnej zapowiedzi męki, śmierci i zmartwychwstania Chrystusa (Mt 16,21; 17,22-23; 20,17-19), a mimo to wyczuła stosowną chwilę i dokonała prorockiego czynu. Jak się okazało, namaszczenie Jezusa było nie tylko gestem miłości, miłosierdzia, szacunku i adoracji, lecz również odnosiło się do Jego pogrzebu. Warto pamiętać, że ewangelista Mateusz nie wspomniał w swoim dziele o tym, że ciało Chrystusa zostało namaszczone po ściągnięciu z krzyża. Choć nie znamy imienia bohaterki tej perykopy, to jednak — zgodnie z tym, co zapowiedział Jezus - historia o niej nie zapomniała. Jej czyn (jakże kontrastujący z postawami arcykapłanów, starszych ludu i Judasza) jest i dzisiaj wspominany na całym świecie — wszędzie tam, gdzie jest głoszona Dobra Nowina.

\section{The anointing of Jesus at Bethany (Matt. 26:6-13)}

\section{Summary}

The action of pericope that describes the anointing of Jesus (Matt. 26:6-13) took place in Bethany, in Judea. These areas were then part of the Great Roman Empire. Christ foretold that the woman who poured out the precious oil on His head in the house of Simon the Leper would know the whole world. That is what exactly happened. Many Christians do not know much about history of the Roman Empire, but probably everyone has heard of a nameless woman who anointed Jesus shortly before His passion and death. The woman embarrassed the apostles, her generous gesture toward Christ contrasted with the conspiracy of the chief priests and the elders of the people (Matt. 26:3-5) and the betrayal of Judas (Matt. 26:14-16).

\section{Keywords}

Bethany, nameless woman, precious oil, anointing, Jesus' head, good deed, burial 


\section{Słowa kluczowe}

Betania, anonimowa kobieta, drogi olejek, namaszczenie, głowa Jezusa, dobry uczynek, pogrzeb

\section{Bibliografia}

Albrecht G., Albrecht M., Matthew, Milwaukee 1996.

Banaszek A., Relacja o wydarzeniu w Betanii w świetle analizy literacko-historycznej (Mt 26,6-13; Mk 14,3-9; Łk 7,36-50; J 12,1-11), w: Studia z biblistyki, t. VII, red. R. Bartnicki, Warszawa 1994, s. 163-240.

Bartnicki R., Przygotowania do śmierci Jezusa (Mk 14,1-11), „Warszawskie Studia Teologiczne" 27 (2014) 2, s. 203-221.

Brzegowy T., Doroczne święta pielgrzymkowe Izraela, „Ruch Biblijny i Liturgiczny” 36 (1983), s. 98-115.

Davies W., Allison D., A Critical and Exegetical Commentary on the Gospel According to Saint Matthew, London-New York 2004.

Fausti S., Wspólnota czyta Ewangelię według św. Mateusza, thum. zbiorowe, Częstochowa 2007.

Gardner R., Matthew, Scottdale 1991.

Garland D., Reading Matthew. A Literary and Theological Commentary on the First Gospel, Macon 2001.

Gnilka J., Das Matthäusevangelium, (Herders Theologischer Kommentar zum Neuen Testament: I/2), Freiburg 1988.

Grundmann W., Das Evangelium nach Matthäus, (Theologischer Handkommentar zum Neuen Testament 1), Berlin 1981.

Hieronim ze Strydonu, Komentarz do Ewangelii wedtug św. Mateusza, (Źródła Myśli Teologicznej), Kraków 2008.

Homerski J., Ewangelia według św. Mateusza. Wstęp — przekład z oryginału — komentarz, (Pismo Święte Nowego Testamentu: III/1), Poznań 2004.

Keener C.S., Komentarz historyczno-kulturowy do Nowego Testamentu, tłum. Z. Kościuk, (Prymasowska Seria Biblijna), Warszawa 2000.

Luz U., Koester H., Matthew 21-28. A Commentary, transl. J.E. Crouch, MinneapolisAugsburg 2005.

Milne M., Betania, w: Encyklopedia biblijna, red. P. Achtemeier, red. wyd. pol. W. Chrostowski, thum. M. Pachciarek, Warszawa 1999, s. 91-92.

Nalewaj A., Opis namaszczenia w Betanii w czwartej Ewangelii (J 12,1-8) w świetle lektury Pieśni nad pieśniami, w: Jak śmierć potężna jest miłość. Księga pamiątkowa ku czci Księdza Profesora Juliana Warzechy SAC (1944-2009), red. W. Chrostowski, Ząbki 2009, s. 270-286. 
Nestle E., Nestle E., Aland B., Aland K., Karavidopoulos J., Martini C., Metzger B., Novum Testamentum Graece, Stuttgart $2013^{28}$.

Newman B., Stine P., A Handbook on the Gospel of Matthew, New York 1992.

Nolland J., The Gospel of Matthew. A Commentary on the Greek Text, Grand Rapids-Carlisle 2005.

Paciorek A., Ewangelia wedtug świętego Mateusza (rozdziały 14-28). Wstęp — przekład z oryginału — komentarz, (Nowy Komentarz Biblijny: Nowy Testament I/2), Częstochowa 2008.

Popowski R., Coleman L., Nowy Testament dla moderatorów, (Prymasowska Seria Biblijna), Warszawa 2010.

Rosik M., Duszpasterski komentarz do Nowego Testamentu. Ewangelia wg św. Mateusza (Mt 14,1-28,20), Tarnów 2010.

Sand A., Das Evangelium nach Matthäus, Regensburg 1986.

Szymik S., Jezus jako gość w świetle ewangelii kanonicznych, „Biblica et Patristica Thoruniensia" 9 (2016) 2, s. 125-141.

Świderkówna A., Rozmowy o Biblii. Nowy Testament, Warszawa 2000.

Watson J., Stowo greckie na każdy dzień roku. Inspiracje z Nowego Testamentu, thum. W. Tasak, Warszawa 2017. 